\title{
Experimental and analytical investigations of reinforced concrete beams strengthened by different CFRP sheet schemes
}

\author{
Khaled Fawzy, Hilal Hassan, M. Madqour \\ University of Zagarig, Egypt \\ khaled_lashen1@yahoo.com, bttps://orcid.org/0000-0003-2275-4025 \\ bilalcivil@yahoo.com \\ Madqour42@gmail.com, bttps:/ /orcid.org/0000-0002-0994-2884
}

\begin{abstract}
The use of reinforced fibre polymers to strengthen and repair structural elements is widely spreading. However, there is lack of knowledge of the actual behavior of strengthened structures with FRP sheets. This paper discusses the experimental results of the flexural strengthening of reinforced concrete (RC) beams by carbon fibrereinforced polymer (CFRP) sheets bonded by epoxy adhesive to the tensile surface of the beams. Using a four-point bending load system over an effective span of $1800 \mathrm{~mm}$, a total of ten beams with an overall dimension of $150 \mathrm{~mm} * 200 \mathrm{~mm} * 2000 \mathrm{~mm}$ with different degrees of strengthening schemes were tested. The number of layers, strengthening scheme (side and U-shape bonding) and reinforcement ratio are the major parameters of the experimental study. The research indicates that the flexural strength of the beams was substantially improved as the layers of laminate increased (between 31.80 and $71.50 \%$ ) and using $\mathrm{U}$ shape in ends that delay or prevent debonding failure. The experimental results compared to that analytically obtained by using ANSYS model showing acceptable agreement with deviations varying no more than 10 $\%$ for all specimens.
\end{abstract}

KEYWORDS. Strengthening; Carbon fibre reinforced polymer; Deflection; ANSYS; Ultimate strength; Ductility.

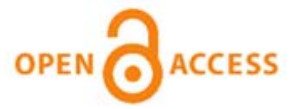

Citation: Fawzi., F., Hassan, H., Madqour., M. Experimental and analytical investigations of reinforced concrete beams strengthened by different CFRP sheet schemes, Frattura ed Integrità Strutturale, 56 (2021) 123-136.

Received: 31.01 .2021

Accepted: 08.03.2021

Published: 01.04.2021

Copyright: (C) 2021 This is an open access article under the terms of the CC-BY 4.0, which permits unrestricted use, distribution, and reproduction in any medium, provided the original author and source are credited.

\section{INTRODUCTION}

7 he external bonding of high-strength CFRP to structural concrete components has gained widespread significance in recent years, particularly in rehabilitation works. due to the various benefits of the use of CFRP as reinforcement, such as corrosion resistance, lightweight, and high strength. The need for bridges, buildings, and other structural elements to be rehabilitated or strengthened may occur due to one or a combination of several reasons including but not limited to construction or design deficiencies, increased load carrying demands, damage to the structural components, and seismic rehabilitation. CFRP was commonly used for strengthening reinforced concrete, masonry, and steel structures. Several studies have shown the suitability of CFRP material for structures made up of different materials, stiffness, and 
ductility [1-4]. By following the proper technique of retrofitting, CFRP greatly improves the shear and flexure strength of concrete structures compared to the standard concrete structure. The epoxy resin which is the adhesive that allows the bond between the concrete surface and CFRP a key parameter for the control for the ultimate strength because it often fails first. Flexure, shear, and compression cracks can be minimized with the help of CFRP technology in RC beams. The use of CFRP compared to other fibre-reinforced polymer (FRP) materials for retrofitting results from its low density, its resistance to elevated tensile forces, fatigue, and corrosion.

Hasnat el al [5] performed research on simply supported RC beams reinforced by CFRP wrap. A CFRP wrap withstood the premature debonding of the cover and acted as a U-clip resulting in an improvement in the capacity of the ultimate moment. Mostafa and Razaqpur [6] carried out an experiment on T-section reinforced concrete beams. The load was applied and the deflection was calculated for each beam. The full post-peak load/softening response of each beam also was obtained. Fu et al. research on the effectiveness of the U-jacket system in preventing or delaying debonding failure has been published. Nine large- range RC beams were studied in their experimental analysis to study and examine the effects of different FRP U-jacket modes on debonding failure. Abid and Al-lami [7] also performed a detailed analysis of previous studies that highlight the strength and durability of concrete beams that have been externally bonded to FRP reinforcement. The study focused on bond behavior, testing approaches, and models used to determine bond strength. Flexure, shear, and fatigue behaviors of multiple reinforcement techniques have been reviewed and discussed in detail. Benaoum el al [2] In this study, 3D-FEM is analyzed in reinforced concrete beams on the basis of a load-deflection reaction analysis. The value of loading magnitude, crack initiation and geometric parameters has been shown. A cracked concrete beam supported by externally bonding CFRP and a concrete beam strengthened by steel bars.

However, the debonding process of collapse, structural ductility, and long-term durability are the major challenges facing CFRP due to weak bonding and decreased vapor pressure [8-12]. flexural strength, failure behavior, and structural ductility are the most important parameters to be considered in structural design, especially when the structure is in high earthquake zone. CFRP is a substance that is brittle and collapses suddenly, and has a linear elastic effect up to failure, i.e., its failure strain in tension varies from $2 \%$ to $4 \%$ [6]. Once the strain of failure has been achieved, CFRP gives no warning signs, it separates suddenly and causes loss of strength. These retrofitted reinforced concrete systems are not ideal because they do not have any sort of early warning before the collapse, resulting in the system collapsing. However, these systems would sustain large loads due to the high strength of the CFRP besides in large deformation/ deflection of the structural member.In this paper the effect of using various layers of CFRP sheets with different U-shape and side bonding schemes is experimentally studied. In addition, a finite element numerical model is performed and the obtained results are compared to the experimental behavior of RC beams in terms of ultimate load, crack patterns, and failure modes.

\section{EXPERIMENTAL PROGRAM AND SETUP}

\section{Test specimens}

en reinforced concrete beams under a monotonical four-point loading scheme were tested in this research work. All the ten beam specimens have the same cross-section $200 \mathrm{~mm}$ height and $150 \mathrm{~mm}$ width, and a length of $2000 \mathrm{~mm}$ (Fig.1). The beams were simply supported with $1800 \mathrm{~mm}$ of clear span. The lower longitudinal reinforcement for beams B00 to B07 was two $10 \mathrm{~mm}$ bars. Two $12 \mathrm{~mm}$ bars were used for B09, and $16 \mathrm{~mm}$ for B08. The upper longitudinal reinforcement of all specimens consisted of two $8 \mathrm{~mm}$ bars. The stirrups were $6 \mathrm{~mm}$ diameter placed at intervals of 125 $\mathrm{mm}$. The thickness of CFRP laminates was $0.129 \mathrm{~mm}$, while their ultimate strain and elasticity module was $1.55 \%$ and 230 GPa, respectively.

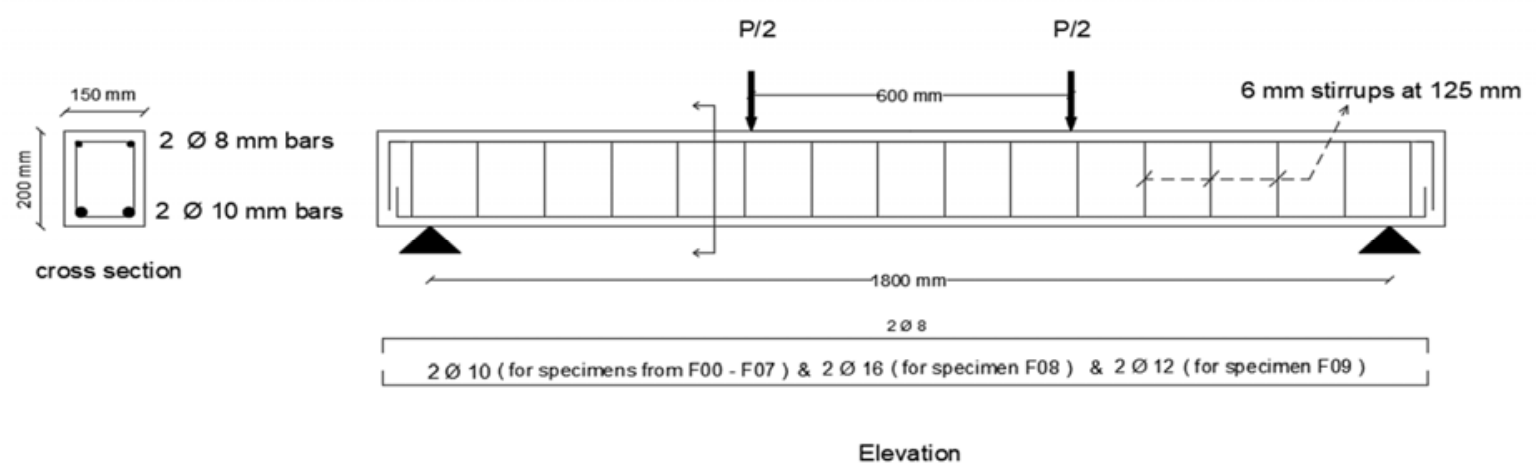

Figure. 1. Details of the tested beams (in $\mathrm{mm}$ ). 


\section{Material properties}

CFRP: The fibre used in the experimental work is longitudinal, unidirectional wrap of Carbon Fibre (Fig. 2). Tab. 3 displays the main features of the manufactured CFRP strengthening material used for the tests.

Epoxy adhesive: The epoxy adhesive consists of two-part; resin (component A) and hardener (component B). Tab. 3 shows a summary of the mechanical and physical characteristics of CFRP impregnation resin used.

Concrete and steel: To achieve concrete mix constituents with a strength of $32 \mathrm{~N} / \mathrm{mm}^{2}$, the concrete mixture was designed using the ACI method. For each casting process, three standard concrete cubes $(150 \mathrm{~mm} \times 150 \mathrm{~mm} \times 150 \mathrm{~mm})$ and three standard concrete cylinders $(150 \mathrm{~mm} \times 300 \mathrm{~mm})$ were cast and cured in water for 28 days. The average of compressive strength after 28 days was $32 \mathrm{MPa}$ (Tab. 1).

Standard tension tests were performed on steel specimens according to ASTM using MTS 200 tons universal testing machine. Three steel specimens were tested for each bar diameter and the average value was considered. the average steel yield stress was $525 \mathrm{MPa}$ for the longitudinal reinforcement and $400 \mathrm{MPa}$ for the stirrups (Tab. 2).

\begin{tabular}{cc}
\hline Properties & Values found in the laboratory \\
Compressive strength $(\mathrm{MPa})$ & 32 \\
Modulus of elasticity $(\mathrm{GPa})$ & 30.6 \\
Modulus of rupture $(\mathrm{MPa})$ & 3.4 \\
\hline
\end{tabular}

Table 1: Concrete properties.

\begin{tabular}{ccc}
\hline Reinforcement type & Yield strength $(\mathrm{MPa})$ & Modulus of elasticity $(\mathrm{GPa})$ \\
Tension $(10 \mathrm{~mm})$ & 525 & 200 \\
Compression $(8 \mathrm{~mm})$ & 525 & 200 \\
Shear $(6 \mathrm{~mm})$ & 400 & 195 \\
\hline
\end{tabular}

Table 2: Steel properties.

\begin{tabular}{ccc}
\hline Materials & Properties & Values $(\mathrm{GPa})$ \\
& Modulus of elasticity (GPa) & 230 \\
& Elongation at ultimate (\%) & 1.70 \\
CFRP laminates & Design thickness (mm/ply) & 0.129 \\
& Tensile strength (MPa) & 4000 \\
& Density $\left(\mathrm{g} / \mathrm{cm}^{3}\right)$ & 1.82 \\
\hline \multirow{3}{*}{ Epoxy (the mix) } & Modulus of elasticity (GPa) & 4.50 \\
& Elongation at ultimate (\%) & 0.90 \\
& Tensile strength (MPa) & 30 \\
\hline
\end{tabular}

Table 3: CFRP laminates and epoxy adhesive properties.

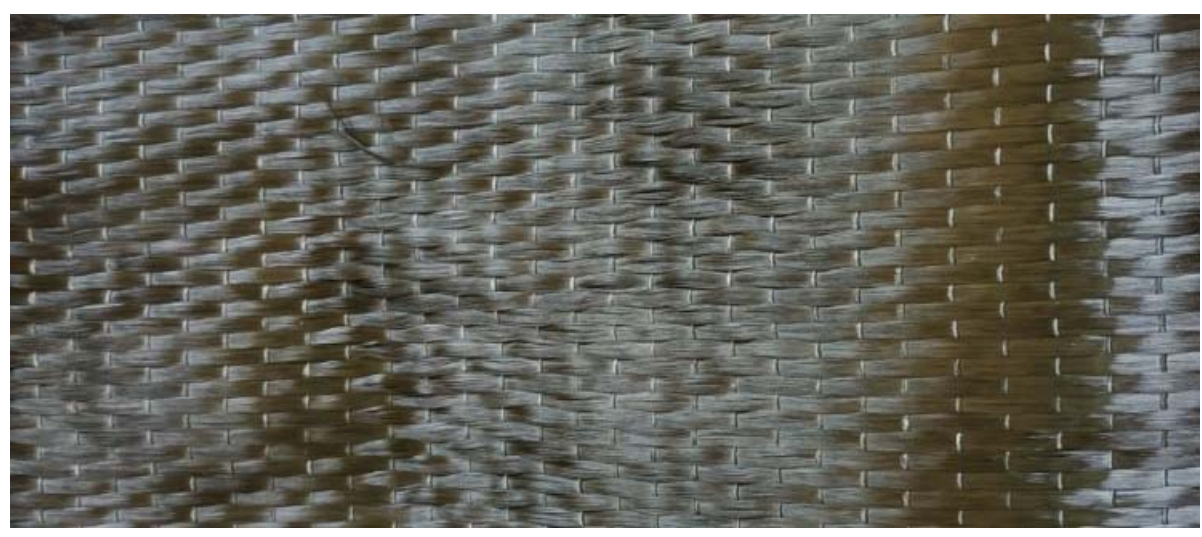

Figure 2: CFRP sheet used in this study. 


\section{Strengthening and instrumentation}

Concrete was poured into the moulds in three layers by using the vibrator to eliminate the appearance of voids. To achieve a smooth surface, the extra concrete was removed. At ambient temperature for 24 hours, the beams, cubes, and cylinders were coated with plastic sheets, then separated from the moulds and numbered. The curing process for the beams was carried out by using a wet sackcloth for 28 days, while the concrete cubes and cylinders were submerged in clean water. the surface of the concrete beams was cleaned to remove the weak strip of dry cement paste and then the dust was removed by air nozzle to achieve perfect bonding. The bonding onto the concrete surface of one or more layers of CFRP was carried out according to the following procedure. Firstly, concrete surfaces were covered with a continuously thick adhesive layer for even surface impregnation, the fabric was cut at the desired size, the adhesive penetrates completely into the fabric's open spaces by using flexible roller. Subsequently, the second layer of adhesive was immediately applied to create a uniform layer of bonded surface reinforcement on top of the fabric. The second adhesive layer was applied in the direction of the fibres with a trowel without excessive pressure and movements. The process was repeated as additional layers of fabric in Fig. 3.

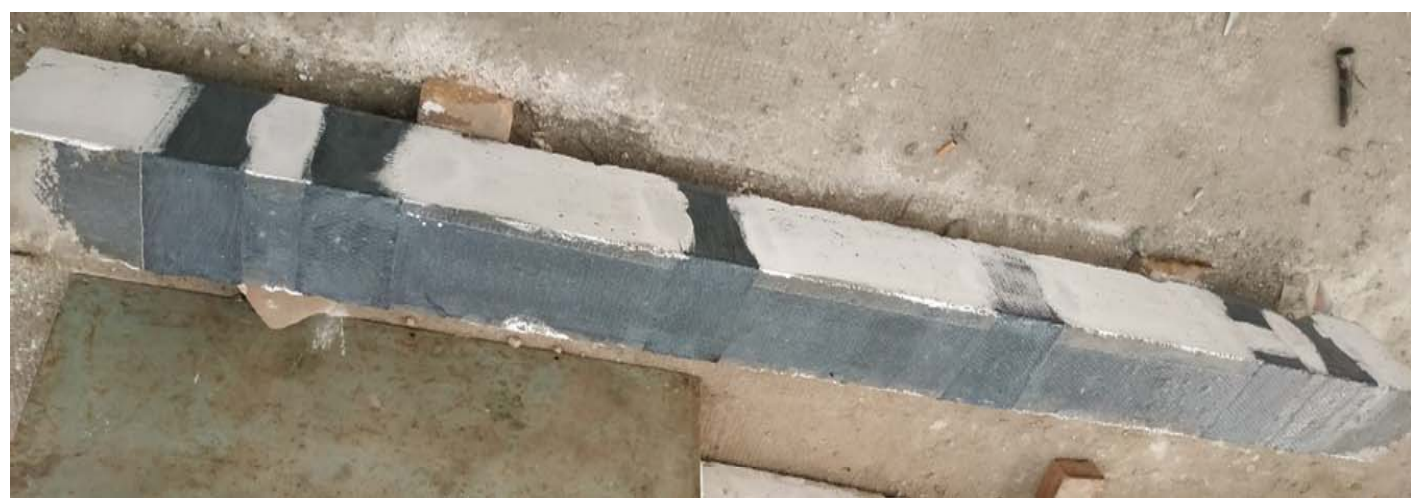

Figure 3: beam after the installation of CFRP.

Beam strengthening included different layers of CFRP and different schemes reported as in Tab. 4. The beams were subjected to a monotonic load up to failure using a $200 \mathrm{kN}$ hydraulic jack. By Using linear variable displacement transducers LVDT, the deflection of all specimens was measured at the mid span as in Fig. 4.

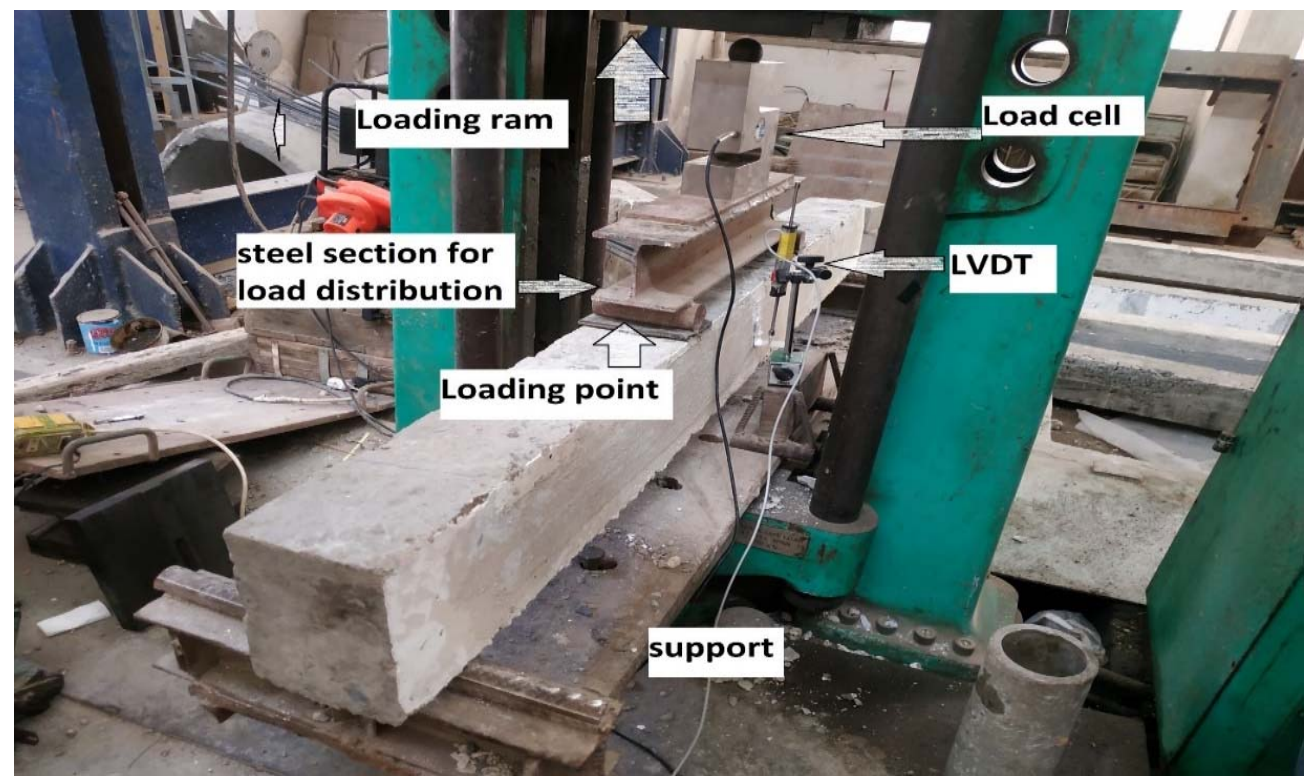

Figure 4: Test Set-up. 


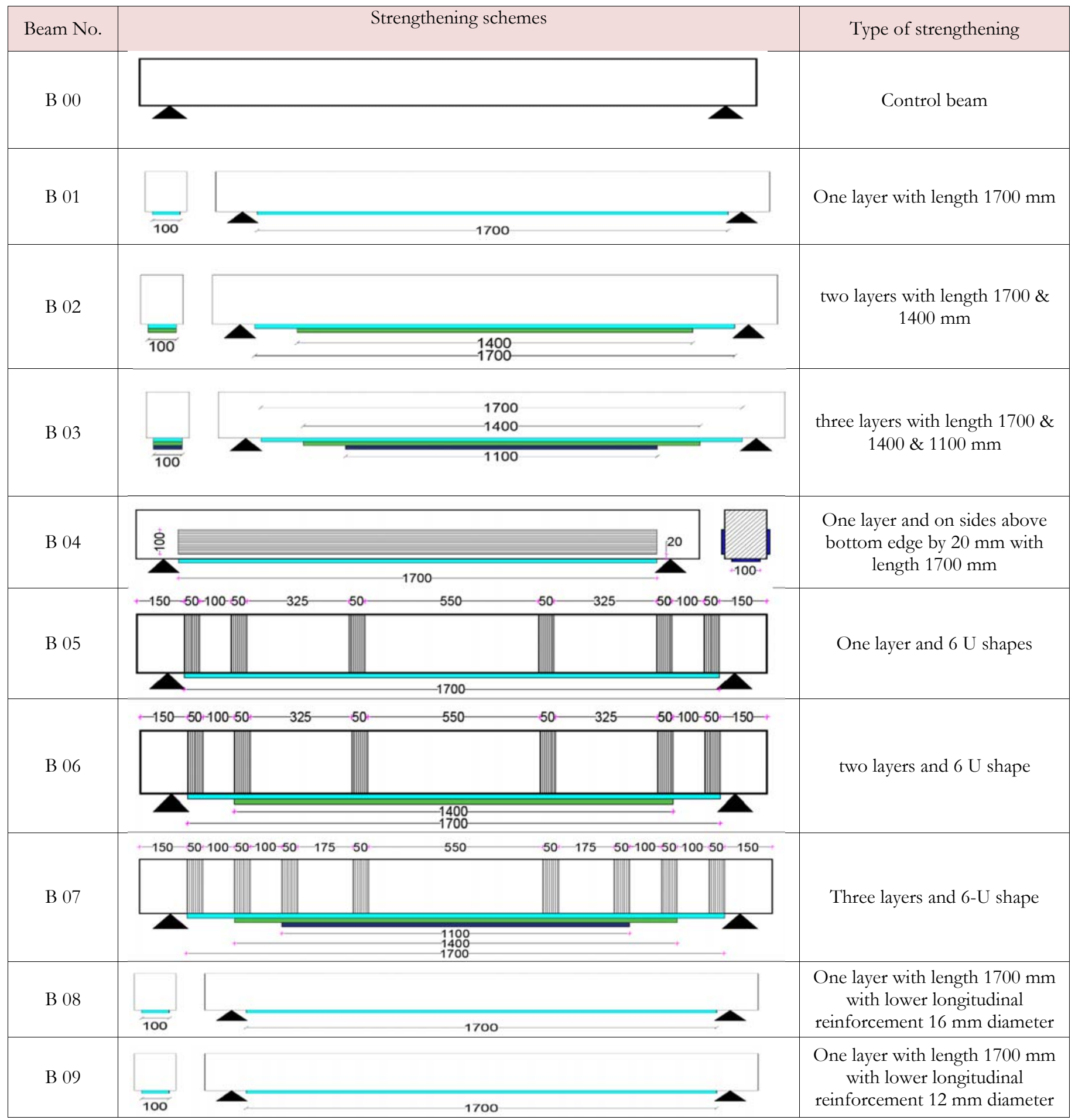

Table 4. Strengthening scheme.

\section{Deflection and failure modes}

The mechanisms of failure can be categorized in global failure and local failure [13-15].

- global failure involves compression failure of concrete in bending before or after yielding of steel, rupture of FRP layer in tension, and shear failure of concrete. 
- local failure is characterized in some places with high interfacial peeling or shear stresses, which may cause the debonding of the composite layer from the concrete beam.

Various failure modes, controlled by the mechanical properties of the materials and the strengthening configuration was founded in the tested specimens.

\section{EXPERIMENTAL RESULTS}

\section{Control beam}

7 he reference beam B00 had a yield load of $39.9 \mathrm{kN}$ and a maximum load of $51.20 \mathrm{kN}$. The beam failure began with the yield of steel, then very high ductility values were observed, steel tension failure was observed at mid-span. The ultimate deflection was $32.01 \mathrm{~mm}$ (see also Tab. 5).

\section{One layer strengthening of beams}

Beam B01 was strengthened with a single layer parallel to the bottom surface of the beam. The beam reinforcement reached its yield at a load of $59.70 \mathrm{kN}$ and supported a maximum load of $69.44 \mathrm{kN}$ with strength gain of $135 \%$ compared with the control beam, while its deflection at failure reached $27.72 \mathrm{~mm}$. Beam B01 showed higher initial stiffness. At mid-span, flexure cracks started, followed by debonding of the CFRP as in Fig. 8.

Specimen B04 with strengthened with one layer on the soffit of the specimen and on sides. The ultimate load was $75.66 \mathrm{kN}$ with a strength increase of $148 \%$. The final failure occurred by rupture of CFRP in the lower chord and then on sides of the beam after concrete crushing in compression at mid-span at a deflection of $31.74 \mathrm{~mm}$.

Beam B05 had one sheet with a width of $100 \mathrm{~mm}$ attached on the bottom chord and $6 \mathrm{U}$ shape sheets with a width of 50 $\mathrm{mm}$ wrapped on the bottom and on the sides to prevent CFRP debonding. The ultimate load was $73.76 \mathrm{kN}$ with a strength increase of $144 \%$. The failure was ductile because the deflection at failure was approximately twice the deflection at the yield of steel reinforcement. At the mid-span, flexure cracks occurred, followed by CFRP sheet rupture at the bottom chord.

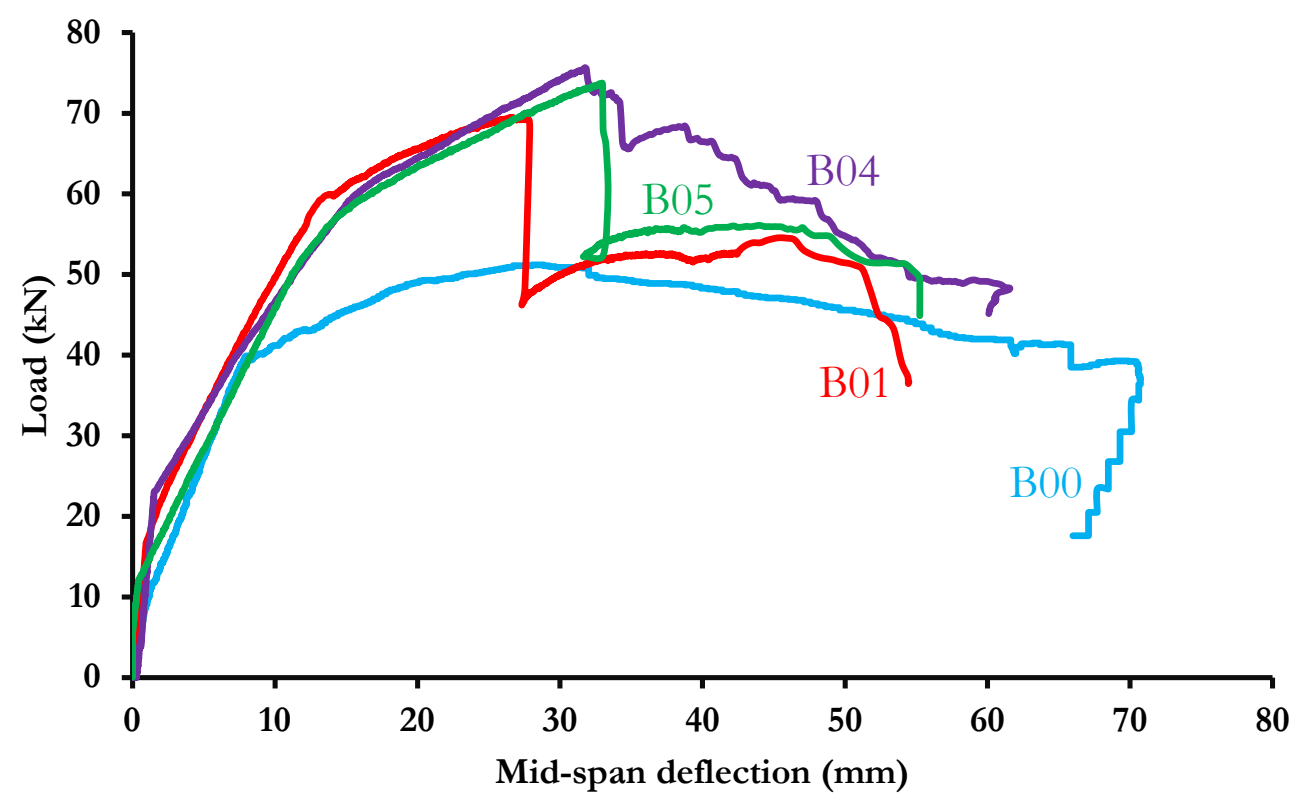

Figure 5: load-deflection curve for one-layer beams.

\section{Two and three layers strengthening of beams}

Beam B02 was reinforced with two layers of CFRP. The strengthening was applied on the bottom of the beam with unequal lengths $(1700 \mathrm{~mm}$ and $1400 \mathrm{~mm}$ ). The yield load was $62.72 \mathrm{kN}$ and the ultimate load was $75.10 \mathrm{kN}$, which represents a gain in strength of $147 \%$. The beam failure was sudden and brittle due to the rupture of the reinforcing composite material. The beam failure was sudden and brittle in form of rupture of the reinforcing composite material. Several flexural cracks occurred 
in the central span of the beam before the composite material failed. The maximum deflection at failure was $27.58 \mathrm{~mm}$ as in (Fig. 8).

The strengthening of beam B06 was similar to Beam B05, except for the number of layers, which is two rather than one. The rupture started with the CFRP wrapped sheets and then the CFRP bottom chord, at the final load of $87.85 \mathrm{kN}$ and the ultimate deflection of $36.96 \mathrm{~mm}$.

Beam B03 was strengthened with 3 layers of CFRP, and the failure occurred in the concrete compression zone, followed by the rupture of CFRP. The maximum load was $79.39 \mathrm{kN}$, which is higher than B00 by $155 \%$, and the maximum deflection was $23.33 \mathrm{~mm}$.

specimen B06 with two strengthening layers and 6 U-shape sheets had a maximum load of $87.85 \mathrm{kN}$ with a strength gain of $172 \%$ compared with B00. At mid-span, more cracks started, followed by debonding of the CFRP (Fig. 8).

beam B07 with three layers and 6U-shape sheets showed that had a maximum load of $88.78 \mathrm{kN}$ with approximately $2 \%$ strength gain compared with B06, the deflection was 30.97.

(a)

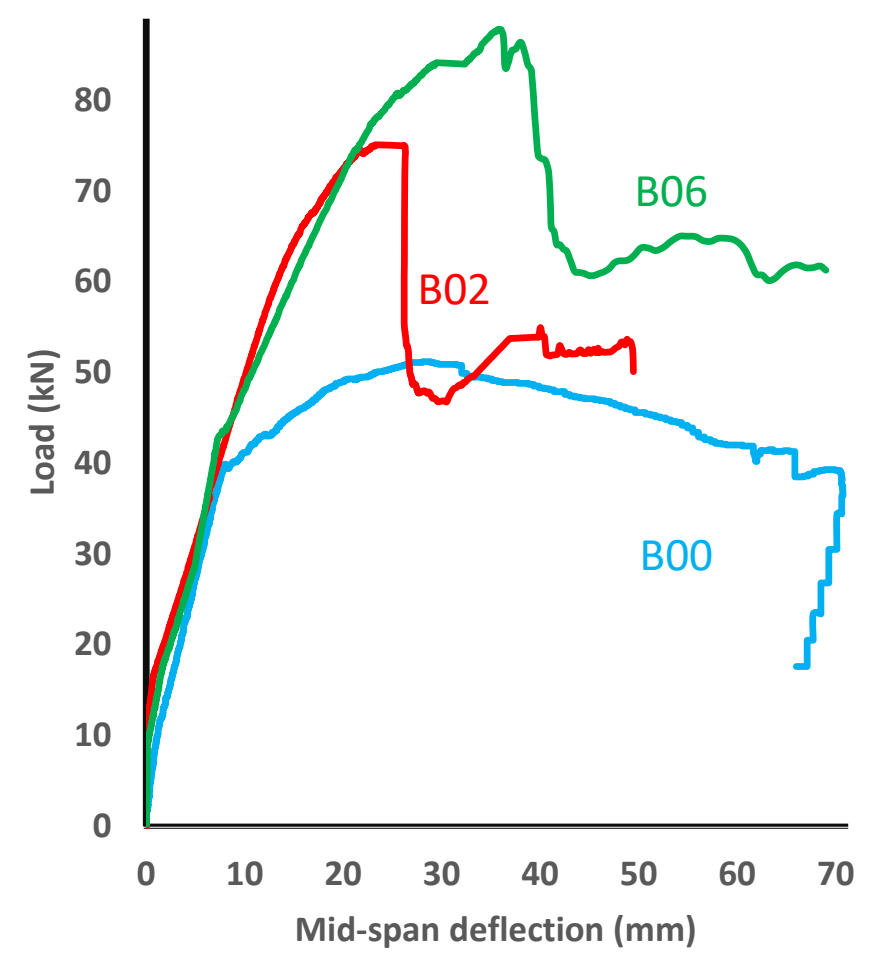

(b)

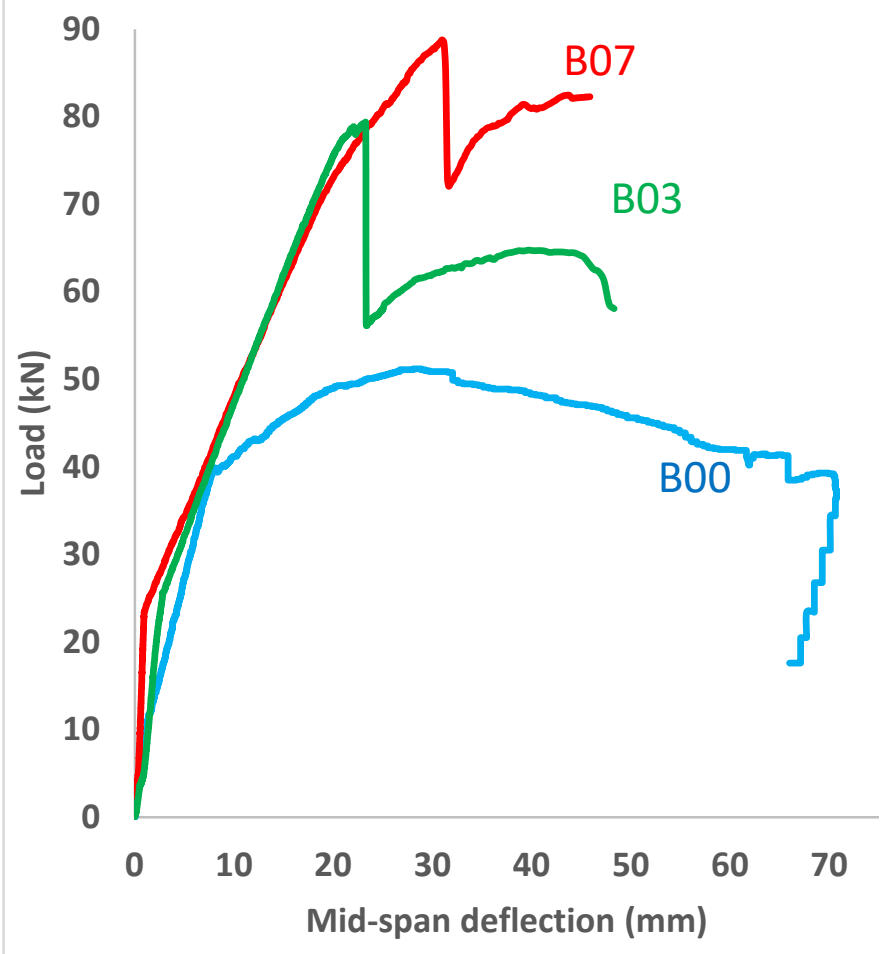

Figure 6: Comparison of the load vs. mid-span deflection of: (a) beams strengthened by two layers CFRP, (b) beams strengthened by three layers CFRP.

\section{Different reinforcement strengthening of beams}

Specimens B08 and B09 were strengthened by one layer of CFRP with different reinforcement ratio. Their ultimate loads increased by $43 \%$ and $16 \%$ compared with B01, respectively. For B08 large shear cracks with almost $45^{\circ}$ from supports. The beam failed completely at the load of $99.08 \mathrm{kN}$ due to failure in the shear region. But for B09, the failure occurs firstly in concrete compression zone, then rupture of the CFRP sheet at a load of $80.38 \mathrm{kN}$ as in Fig. 8 .

\section{Ductility characteristics}

In the seismic regions, ductility is a significant parameter for the design of concrete structures. The ductility can be evaluated in terms of energy or deflection. For comparison purposes, Thomsen et al. [16] use ductility depended on the concept of energy, $\mu \mathrm{E}$, described as the ratio of the system's energy at failure, Eu, to that of the first steel yield, Ey. The concept of deformation is based on the deflection ductility index (displacement at failure divided by displacement at yield) while the energy ductility is measured as the ratio of the area under the load deflection curve at ultimate failure to the area under the 
load deflection curve at yielding of tension steel. Oudah and Hash [17] recently published a new definition of ductility, a model based on beam deflection and energy. The ductility indexes can be described as:

$$
\begin{aligned}
& \text { Deflection ductility: } \mu \Delta=\Delta \mathrm{u} / \Delta \mathrm{y} \\
& \text { Energy ductility: } \mu \mathrm{E}=\mathrm{Eu} / \mathrm{Ey}
\end{aligned}
$$

Tab. 6 displays the energy and deflection ductility of the prepared RC beams reinforced by using different combinations of CFRP. It was also found that the beam without strengthening displayed greater displacement or ductility relative to concrete beams of different CFRP configurations.

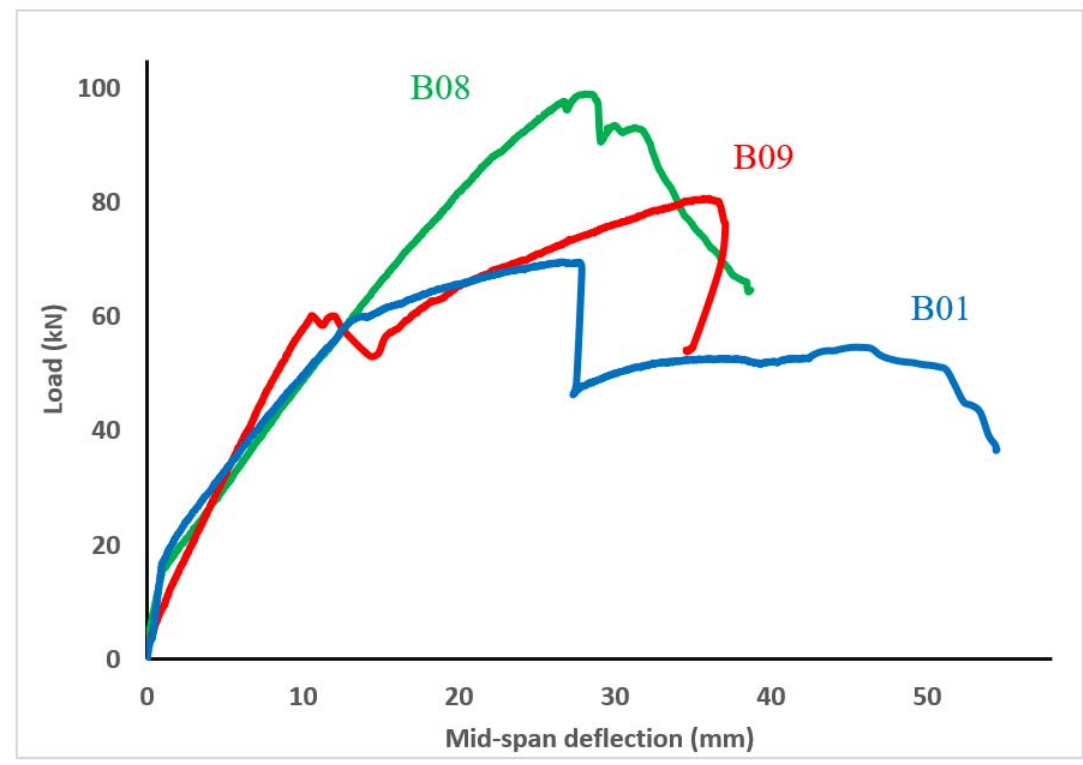

Figure 7: load-deflection curve for one layer with different reinforcement.

\begin{tabular}{ccccccc}
\hline & \multicolumn{3}{c}{ At first crack } & \multicolumn{2}{c}{ At steel yield } & \multicolumn{2}{c}{ At failure } \\
Beam No. & $\begin{array}{c}\text { Load } \\
(\mathrm{kN})\end{array}$ & $\begin{array}{c}\text { Deflection } \\
(\mathrm{mm})\end{array}$ & $\begin{array}{c}\text { Load } \\
(\mathrm{kN})\end{array}$ & $\begin{array}{c}\text { Deflection } \\
\Delta \mathrm{y}(\mathrm{mm})\end{array}$ & $\begin{array}{c}\text { Max Load } \\
(\mathrm{kN})\end{array}$ & $\begin{array}{c}\text { Deflection } \\
\Delta \mathrm{u}(\mathrm{mm})\end{array}$ \\
B 00 & 11.80 & 1.98 & 39.9 & 8.35 & 51.20 & 32.01 \\
B 01 & 16.73 & 2.1 & 59.7 & 14.10 & 69.44 & 27.72 \\
B 02 & 26.32 & 6.45 & 62.72 & 14.32 & 75.1 & 26.13 \\
B 03 & 25.59 & 3.45 & 63.88 & 14.88 & 79.39 & 23.33 \\
B 04 & 21.88 & 1.51 & 60.25 & 14.51 & 75.66 & 31.74 \\
B 05 & 13.68 & 1.54 & 60.15 & 16.83 & 73.76 & 32.96 \\
B 06 & 17.47 & 2.56 & 80.50 & 25.61 & 87.85 & 36.96 \\
B 07 & 23.99 & 2.17 & 71.55 & 20.44 & 88.78 & 30.97 \\
B 08 & 15.58 & 1.09 & 88.8 & 23.77 & 99.06 & 33.76 \\
B 09 & 12.17 & 1.46 & 53.07 & 14.27 & 80.38 & 36.56 \\
\hline
\end{tabular}

Table 5: Tested specimen data. 
B 00

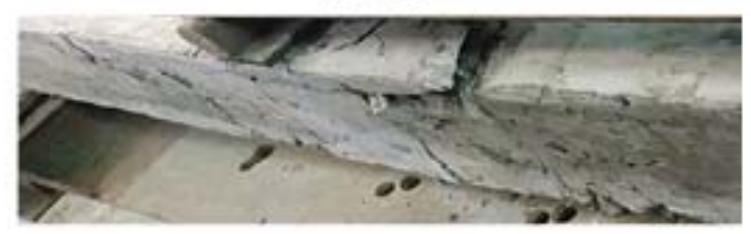

B 02

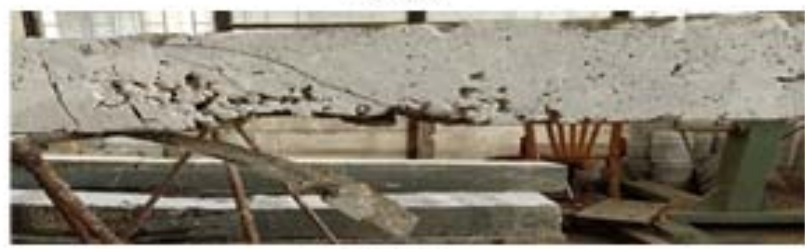

B04

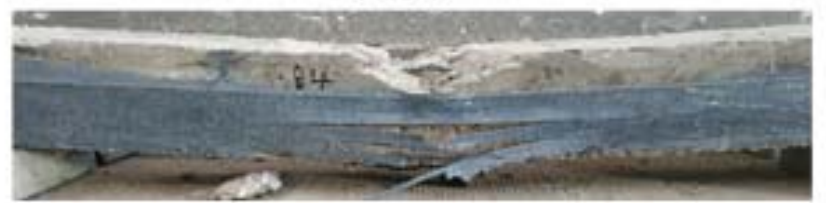

B06

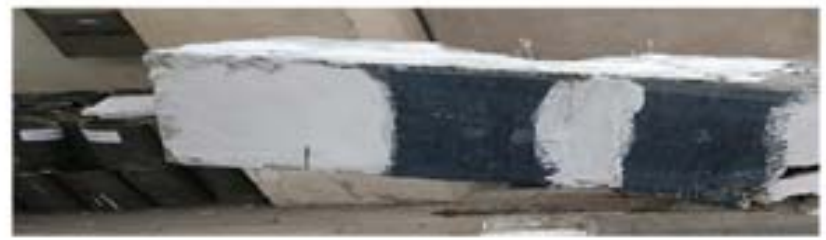

B08

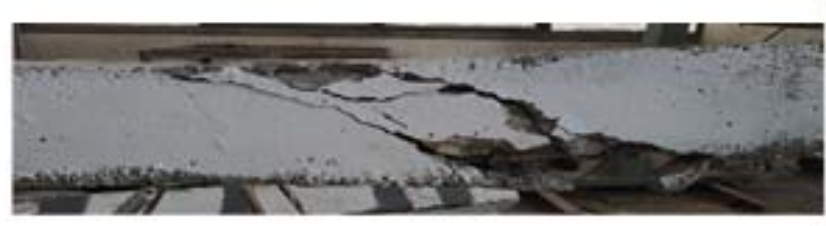

B01

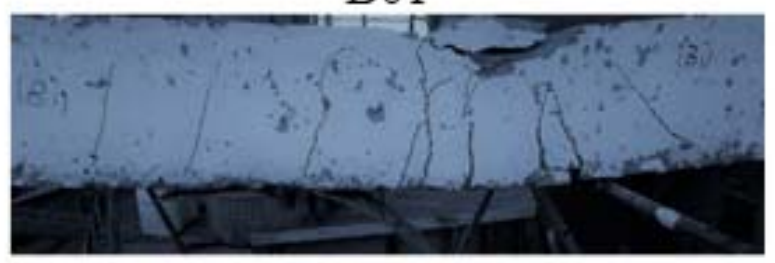

B03

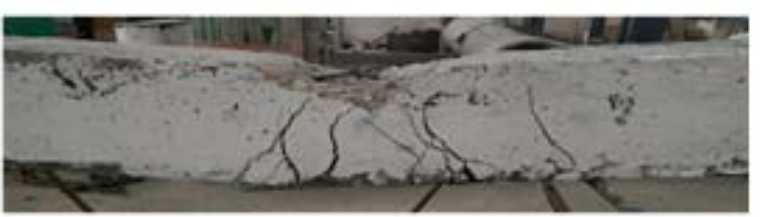

B05

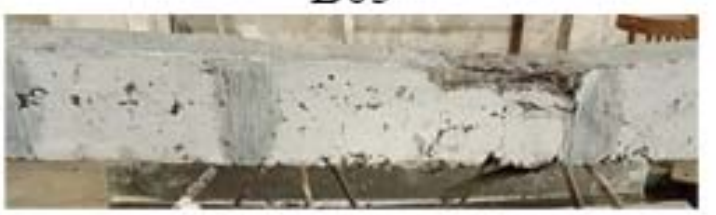

B07

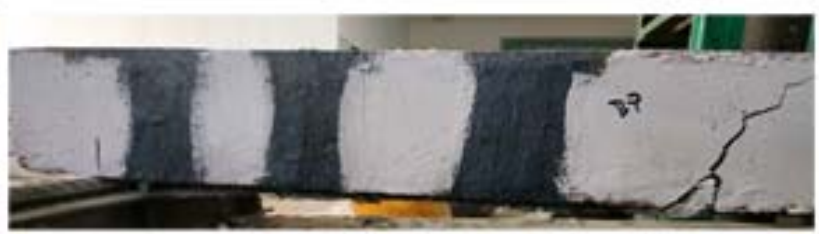

B09

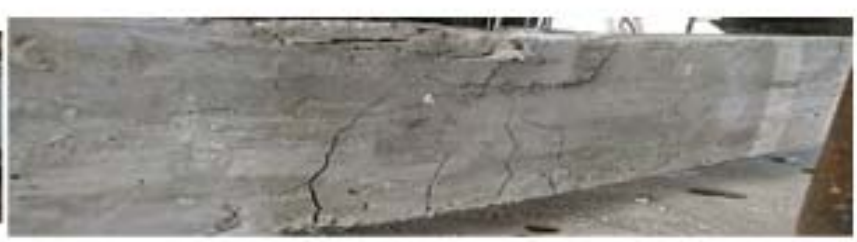

Figure 8: Failure mode of the tested beams.

\begin{tabular}{ccccc}
\hline & \multicolumn{3}{c}{ Ductility } & \multicolumn{3}{c}{ Ductility ratios } \\
Beam No. In terms of deflection In terms of energy In terms of deflection In terms of energy \\
& $\mu \Delta$ & $\mu \mathrm{E}$ & $\mu \Delta$ & $\mu \mathrm{E}$ \\
B 00 & 3.83 & 5.96 & 1 & 1 \\
B 01 & 1.97 & 2.64 & 0.51 & 0.44 \\
B 02 & 1.54 & 1.92 & 0.40 & 0.32 \\
B 03 & 1.57 & 2.08 & 0.41 & 0.35 \\
B 04 & 1.68 & 2.09 & 0.44 & 0.35 \\
B 05 & 1.96 & 2.66 & 0.514 & 0.45 \\
B 06 & 1.49 & 1.64 & 0.39 & 0.28 \\
B 07 & 1.51 & 2.06 & 0.39 & 0.34 \\
B 08 & 1.42 & 1.49 & 0.37 & 0.25 \\
B 09 & 2.56 & 3.70 & 0.67 & 0.62 \\
\hline
\end{tabular}

Table 6: Ductility index. 


\section{VERIFICATION STUDY}

he finite element (FE) models were calibrated with the experimental results. The purpose of this comparison is to verify the validity of the analysis and model. As in the (Fig. 10), there is a really very good correlation between the experimental and numerical load-deflection curves for all loading stages. the FE models were able to predict the Load-carrying capacity of RC beams. The validity and reliability of the FE models established to simulate the experimental performance.

The concrete is modelled using the form of element SOLID65 [18]. This element has eight nodes with three degrees of freedom at each node; translations in the global reference directions $x, y$, and $z$. This element is capable of plastic deformation, cracking and crushing in three orthogonal directions. The nonlinear behavior of geometry and properties of materials for concrete structures was considered in this research according to several sources [2, 19-22], the mechanical properties of concrete, FRP plate and adhesive are selected and are given in Tab. 7.

\begin{tabular}{cccccc}
\hline Material & $\begin{array}{c}\text { Elastic modulus } \\
(\mathrm{GPa})\end{array}$ & Poisson's ratio & $\begin{array}{c}\text { Compressive } \\
\text { strength }(\mathrm{MPa})\end{array}$ & $\begin{array}{c}\text { Yield strength } \\
(\mathrm{MPa})\end{array}$ & $\begin{array}{c}\text { Tensile strength } \\
(\mathrm{MPa})\end{array}$ \\
Concrete & 32 & 0.20 & 32 & 500 & 3.02 \\
Steel bars & 30.6 & 0.30 & & & \\
CFRP & 230 & 0.30 & & \\
Epoxy & 4.50 & 0.30 & & \\
\hline
\end{tabular}

Table 7: Mechanical properties of concrete, steel and CFRP reinforcement.
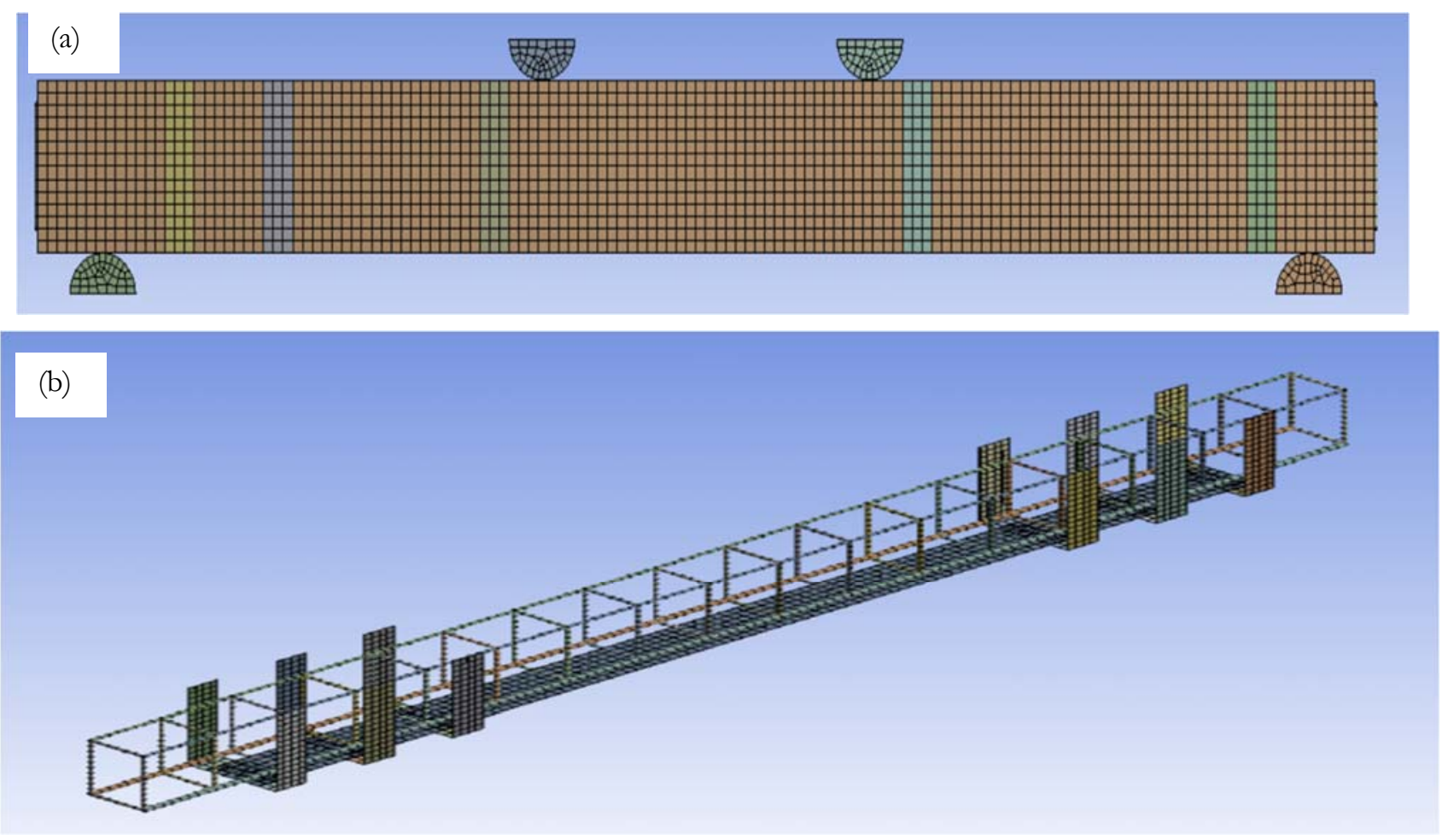

Figure 9: (a) Sample representation of developed FE models., (b) different element of the beam modeled.

Tab. 8 summarizes the comparison of experimental and numerical results achieved for all specimens studied and demonstrates that the analytical approach discussed here can be used to model strengthened beam behavior in a satisfactory way when there is no premature delamination of the strengthened composite material. The proposed ANSYS [23] model results showed acceptable agreement with the experimental results, with deviations of less than $10 \%$. 

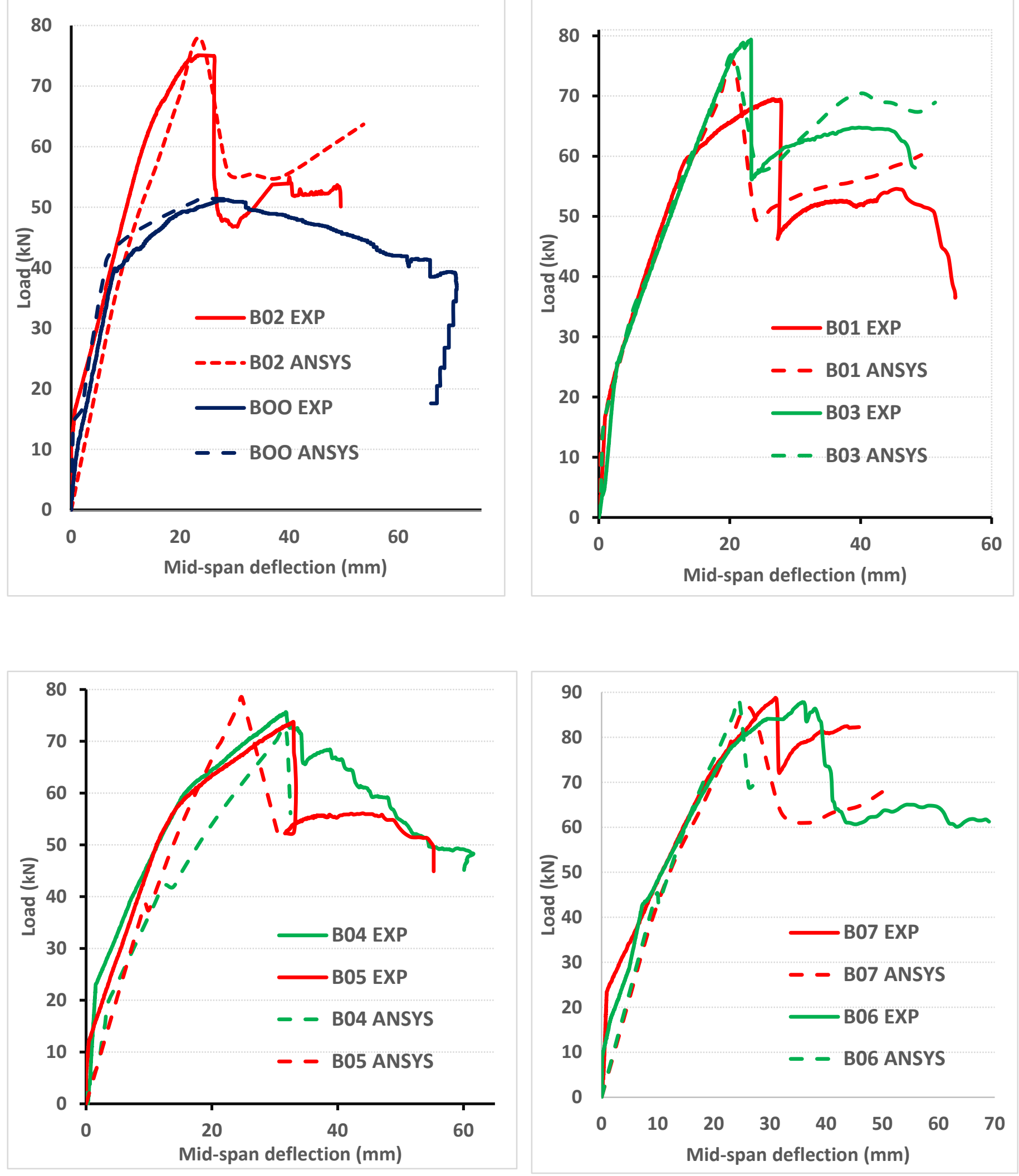


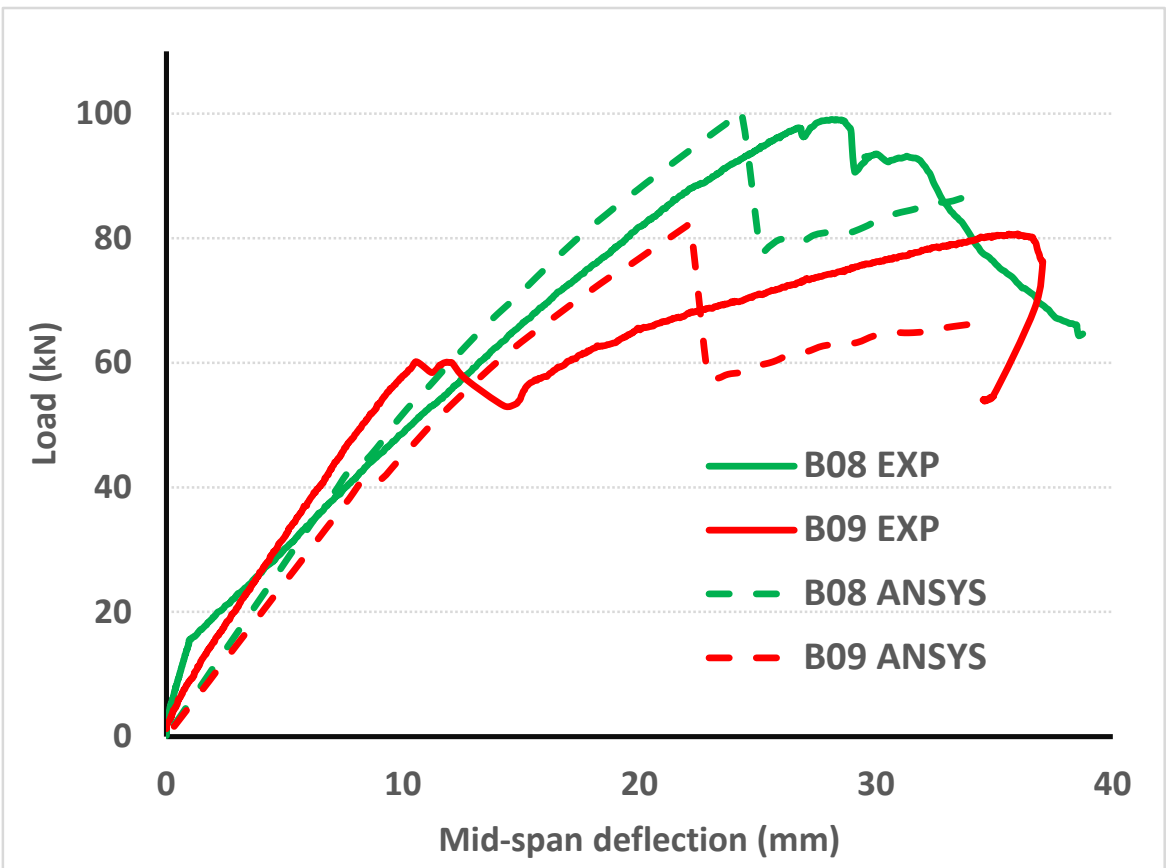

Figure 10: comparison between experimental and numerical load - deflection curve for B00 to B09.

\begin{tabular}{|c|c|c|c|c|c|c|}
\hline \multirow{2}{*}{ Beam No. } & \multicolumn{2}{|c|}{ Theoretical (Ansys) } & \multicolumn{2}{|c|}{ Experimental } & \multirow{2}{*}{$\frac{P_{\text {ult (the) }}}{P_{\text {ult }(e x p)}}$} & \multirow{2}{*}{$\begin{array}{l}\text { Failure mode } \\
\text { (Experimental) }\end{array}$} \\
\hline & $\begin{array}{l}\text { Load } \\
(\mathrm{kN})\end{array}$ & $\begin{array}{c}\text { Deflection } \\
\Delta \mathrm{u}(\mathrm{mm})\end{array}$ & $\begin{array}{l}\text { Load } \\
(\mathrm{kN})\end{array}$ & $\begin{array}{l}\text { Deflection } \\
\Delta \mathrm{u}(\mathrm{mm})\end{array}$ & & \\
\hline В 00 & 51.39 & 30 & 51.20 & 32.01 & 1 & Concrete crushing \\
\hline В 01 & 75.21 & 23.92 & 69.44 & 27.72 & 1.08 & debonding of the CFRP \\
\hline В 02 & 77.67 & 23.82 & 75.1 & 26.13 & 1.03 & Rupture of the CFRP \\
\hline В 03 & 76.39 & 23.69 & 79.39 & 23.33 & 0.96 & Rupture of the CFRP and Concrete crushing \\
\hline В 04 & 72.43 & 31.76 & 75.66 & 31.74 & 1 & Rupture of the CFRP and Concrete crushing \\
\hline В 05 & 78.43 & 24.79 & 73.76 & 32.96 & 1.06 & Rupture of the CFRP \\
\hline B 06 & 88.03 & 24.53 & 87.85 & 36.96 & 1 & Rupture of the CFRP \\
\hline В 07 & 86.43 & 26.48 & 88.78 & 30.97 & 0.97 & Rupture of the CFRP \\
\hline В 08 & 100.15 & 24.3 & 99.06 & 33.76 & 1.01 & Local shear rupture \\
\hline В 09 & 82.25 & 22.56 & 80.38 & 36.56 & 1.02 & debonding of the CFRP \\
\hline
\end{tabular}

Table 8: Comparison between experimental and theoretical results.

\section{CONCLUSIONS}

7 he aim of this analysis is to investigate the influence of different parameters on the flexural behavior of repaired concrete beams, such as the number of layers, strengthening scheme (side and U-shape bonding), and reinforcement ratio. Based on these experimental and numerical results, we can deduce the following:

- The outcome of the experimental program shows that externally bonded CFRP may be used to support reinforced concrete beams effectively. With the increase in CFRP layers, an increase in stiffness and flexural strength was observed. 
- The ultimate load of the beam was increased as the length of the FRP reinforcement was increased.

- The U-shape used to anchor longitudinal CFRP helped to avoid damage due to debonding ends of CFRP and increased flexural strength. This scheme has the best results with strength gain of $174 \%$ compared with control beam.

- Using the CFRP on sides of beams was just more successful than the U-shape.

- FE model showing acceptable agreement with deviations varying no more than $10 \%$ for all specimens.

\section{REFERENCES}

[1] Ahmed, E., Sobuz, H. R. and Sutan, P. S. (2011). Flexural performance of CFRP strengthened RC beams with different degrees of strengthening schemes, International Journal of the Physical Sciences, 6(9), pp. 2229-2238.

[2] Benaoum, F., Khelil, F. and Benhamena, A. (2020). Numerical analysis of reinforced concrete beams pre cracked reinforced by composite materials, Frattura ed Integrità Strutturale, 14(54), pp. 282-296.

[3] Fawzy, K. (2018). Upgraded the Performance of the Fortifying RC beam by CFRP In Flexural, OSR Journal of Mechanical and Civil Engineering (IOSR-JMCE).

[4] Shardakov, I., Shestakov, A. and Bykov, I. S. (2016). "Delamination of carbon-fiber strengthening layer from concrete beam during deformation (infrared thermography), Frattura ed Integrità Strutturale, 10(38), pp. 331-338.

[5] Hasnat, A., Islam, M. and Amin, A. J. J. (2016). Enhancing the debonding strain limit for CFRP-strengthened RC beams using U-clamps: Identification of design parameters, the Journal of Composites for Construction, ASCE, 20(1), p. 04015039.

[6] Mostafa, A. A., Razaqpur, A. G. J. C. (2017). Finite element model for predicting post delamination behaviour in FRPretrofitted beams in flexure, Construction and Building Materials, 131, pp. 195-204.

[7] Abid, S. R. and Al-lami, K. (2018). Critical review of strength and durability of concrete beams externally bonded with FRP, Cogent Engineering, 5(1), p. 1525015.

[8] Triantafillou, T. C. and Plevris, N. (1992). Strengthening of RC beams with epoxy-bonded fibre-composite materials, Materials and Structures, 25(4), pp. 201-211.

[9] Wu, Z., Li, W. and Sakuma, N. (20069. Innovative externally bonded FRP/concrete hybrid flexural members, Composite Structures, 72(3), pp. 289-300.

[10] Uomoto, T. (2001). Durability of FRP reinforcement as concrete reinforcement, in FRP Composites in Civil Engineering. Proceedings of the International Conference on FRP composites in Civil EngineeringHong Kong Institution of Engineers, Hong Kong Institution of Steel Construction, 1.

[11] Ibrahim, Y. E., Fawzy, K. and Farouk, M. A. (in press). Effect of steel fiber on the shear behavior of reinforced recycled aggregate concrete beams, Structural Concrete.

[12] Fu, B., Chen, G. and Teng, J. J. C. S. (2017). Mitigation of intermediate crack debonding in FRP-plated RC beams using FRP U-jackets, Composite Structures, 176, pp. 883-897.

[13] Saadatmanesh, H. and Ehsani, M. R. (1991). RC beams strengthened with GFRP plates. I: Experimental study, Journal of structural engineering, 117(11), pp. 3417-3433.

[14] Chen J. F. and Teng, J. G. (2003). Shear capacity of FRP-strengthened RC beams: FRP debonding, Construction and Building Materials, 17(1), pp. 27-41.

[15] Mahmoud T. E.-M. and Joseph, W. T. (2001). Prediction of Anchorage Failure for Reinforced Concrete Beams Strengthened with Fiber-Reinforced Polymer Plates, ACI Structural Journal, 98(3).

[16] Thomsen, H., Spacone, E., Limkatanyu, S. and Camata, G. J. (2004). Failure mode analyses of reinforced concrete beams strengthened in flexure with externally bonded fiber-reinforced polymers, Structural Concrete, 8(2), pp. 123-131, 2004.

[17] Oudah, F. and El-Hacha, R. (2012). A new ductility model of reinforced concrete beams strengthened using Fiber Reinforced Polymer reinforcement, Composites Part B: Engineering, 43(8), pp. 3338-3347, 2012/12/01/ 2012.

[18] Schesnyak, L. (2019). Modeling of the conjugation of vortex flows with downstream in ANSYS, in IOP Conference Series: Materials Science and Engineering, 675(1), p. 012026.

[19] Bennegadi, M., Sereir, Z. and Amziane, S. (2013). 3D nonlinear finite element model for the volume optimization of a RC beam externally reinforced with a HFRP plate," Construction and Building Materials, 38, pp. 1152-1160.

[20] Bennati, S., Dardano, N. and Valvo, P. S. (2012). A mechanical model for FRP-strengthened beams in bending, Frattura ed Integrità Strutturale, 6(22), pp. 39-55. 
[21] Boulebd, A., Noureddine, F., Mohcene, B. and Mesbah, H. (2020). Modeling of CFRP strengthened RC beams using the SNSM technique, proposed as an alternative to NSM and EBR techniques, Frattura ed Integrità Strutturale, 54, pp. 21-35.

[22] Hawileh, R. J. M. (2015). Finite element modeling of reinforced concrete beams with a hybrid combination of steel and aramid reinforcement, Materials and Design, 65, pp. 831-839.

[23] A. R. J. C. Version, PA, 12.1. 0, A Finite Element Computer Software and User Manual for Nonlinear Structural Analysis, ANSYS Inc, (2009). 